\title{
A região da Reserva Indígena Raposa/Serra do Sol Prévias para seu entendimento
}

AZIZ AB'SÁBER

S SÉRIAS questões que no momento incidem sobre a Reserva Indígena
Raposa/Serra do Sol no Estado de Roraima demonstraram a falta de es-
pírito de planejamento, adaptado caso a caso. Nas polêmicas turbulentas em que se discutem os problemas da reserva, percebe-se a nefasta e simplória atitude de que "uns são contra, outros a favor". Esquecendo-se de analisar metodicamente a essência da área nuclear, em seus aspectos básicos: geológicos, socioambientais ou socioétnicos. Para que não se aceitem ideias simplórias, político-demagógicas, é absolutamente necessário fazer estudos básicos, metódicos e interdisciplinares, dotados de forte sensibilidade bioética.

Para se entender a posição do espaço ocupado pela Reserva Raposa/Serra do Sol, é indispensável um conhecimento mais amplo sobre as territorialidades do Estado de Roraima. No extremo norte do imenso espaço da Amazônia brasileira, estende-se o último setor de terras baixas colinosas regionais, porém envolvidas por serranias florestadas, ao oeste (Serra Parima) e ao norte (Serra Paracaima). Ao contraste fisiográfico superpõe-se um extraordinário uma oposição geoecológica marcante. Nesse sentido, na linguagem popular, desde há algum tempo foram reconhecidos dois conjuntos ecossistêmicos principais no espaço total do Estado: as serranias florestadas de oeste e norte de Roraima constituem espaços de vegetação orográfica tropical úmida, que se estende pelos dois setores da fronteira com a Venezuela. O chamado "lavrado" é constituído por rasas colinas arenosas, de solo inadequado para atividades agrícolas.

Talvez a expressão “lavrado", aplicada pelo povo às colinas de uma larga depressão intermontana regional, derive do fato de que a paisagem dessa subárea dê a impressão de solos degradados por antigas atividades agrícolas. Convém lembrar também que nessas colinas arenosas ocorrem estreitas e alongadas florestas beiradeiras, embandeiradas pelas folhas de magníficos buritizais. Os minirredutos, cerrados observáveis em alguns raros pontos da região, permitem-nos identificar o "lavrado" como uma área de campestres, similares aos solos arenosos ao oeste da Serra dos Caiapós, no sudeste de Goiás. Lindas paisagens de uma fácies do domínio dos cerrados, infelizmente impróprias para atividades agrícolas. Um ambiente geoecológico de grande risco para extensão de queimadas, tal como foi o caso das grandes queimadas em Roraima em meados do ano 2000. 
Os campestres terminam bruscamente ao norte de Roraima, nos sopés das serranias oeste-leste ocorrentes na borda da "Grã-Sabana" venezuelana. De tal forma que nas áreas fronteiriças com o país vizinho podem-se identificar as serranias florestadas dirigidas de sul para o norte, enquanto ao norte ocorrem as florestas tipicamente orográficas de direção oeste-norte, em relação às cimeiras da chamada Grã-Sabana e altiplano dos Tepuy's. O pesquisador que viaja de Boa Vista para o norte, além do pontão rochoso da Pedra Pintada, encontra um lugar altamente significante, nos sopés das serranias fronteiriças, onde os roceiros ocasionais chamam de "borda da mata", velha expressão portuguesa encontrada por convergência no extremo norte da Amazônia brasileira. Não é preciso dizer que ali se findam os campestres em solos arenosos e se iniciam ascendentemente os solos vermelhos tropicais (oxissolos).

O fato de as matas das serranias florestadas de Roraima - existentes ao oeste e ao norte do Estado - possuírem solos tropicais do tipo dos oxissolos criou grandes problemas para homens e natureza nessas regiões de Roraima (Serra Parima, sobretudo). Isso porque nos recantos "amorreados" da área de junção entre as florestas de oeste e as de norte viviam os Yanomami, grupos humanos herdeiros de uma longa pré-história da América do Sul setentrional, o mais típico caso de "refúgios de homens" existentes em toda a Amazônia. A expansão caótica das fronteiras agrícolas em diversas porções das terras amazônicas, a partir dos anos 1960, atingiu logo subáreas diversas da "Serra" florestada de oeste, processo feito pela compra fraudulenta de glebas, invasões planejadas ou concessões governamentais. Episódios que multiplicaram derrubadas e queimadas para o estabelecimento de rústicas fazendas em setores multivariados do território habitado pelos índios Yanomami, culminando pelo último grande incêndio regional dos fins do século XX, no estremo norte da Amazônia.

Concomitantemente à multiplicação de fazendas por alienígenas residentes nas mais diversas regiões do Brasil, multiplicaram-se os pontos de garimpagens nos sopés das serranias de oeste e noroeste de Roraima. Era uma atividade mais antiga na região, mas que inesperadamente teve mais incentivos por causa do surgimento da rodovia de Boa Vista para BV8/Venezuela, envolvendo caminhos rústicos, nas terras situadas nos sopés das serras florestadas, em locais de onde os rios provindos das áreas montanhosas depositaram aluviões subatuais em planícies de piemonte. Além disso, as atividades de garimpagem tornaram-se enriquecedoras para especuladores continuarem residentes em Boa Vista e Manaus ou alhures, tendo a seu favor o trabalho semiescravo de garimpeiros vindos de toda parte. As personagens enriquecidas com as atividades dos garimpeiros chegaram a construir pequenas campos de aviação para facilitar a gestão rentável de seus garimpos.

As discussões frequentes e conflitantes que vêm acontecendo sobre a Reserva Indígena Raposa/Serra do Sol, que ocupa um espaço total da ordem de $10.700 \mathrm{~km}^{2}$ no nordeste de Roraima, exigem análises mais equilibradas e planos mais inteligentes e adequados. No momento, só existem duas campanhas opos- 
tas. Uns querem que o espaço seja transformado em um modelo descontínuo; outros exigem que a reserva seja mantida com a demarcação total vigente. Tais proposições, transformadas em verdadeiras campanhas, repetem um esquema de ocorrência lamentável em torno de assuntos sérios, que poderiam receber propostas mais adequadas e inteligentes.

Durante as decisões metódicas feitas em um evento sobre políticas públicas Sul/Sul, em Manaus, tratou-se o assunto das reservas indígenas com um tratamento multidisciplinar. Na ocasião houve total acordo sobre a necessidade de se realizarem estudos básicos, por pessoas competentes, sobre a demarcação de novas reservas; e, por extensão, o muito que se deve detalhar e propor para os casos de reservas já legalmente demarcadas. Esse último é o caso mais complexo, porque exige conhecimentos variados, equilíbrio e vontade de proteger os herdeiros da pré-história contra especuladores de qualquer procedência, ou seja, contra os criptoespeculadores, que nunca deixam entrever os interesses maiores visados em suas propostas.

Nas discussões realizadas em Manaus, insistimos muito sobre a questão das "zonas-tampão" ("buffer zones") no entorno de reservas indígenas, de qualquer área de extensão e posição geográfica. $\mathrm{O}$ ideário das faixas ditas tampões tem objetivos variados: 1. evitar o encarceramento radical de grupos semiaculturados; 2 . proteger a reserva indígena em relação aos especuladores ansiosos por conquistar espaços e explorar recursos minerais de eventuais parcelas de agrobusiness; 3. orientação para os grupos semiaculturados cujas aldeias estejam vizinhas de cidades ou espaços rurais muito ocupados; 4. presença de órgãos representativos do Estado brasileiro (Incra, Ministérios da Saúde, Educação e Cultura), jovens universitários, agrônomos, advogados, antropólogos, sociólogos e psicólogos: na categoria de estagiários e aprendizes. Cada tipo de reserva deveria receber um rol de atenções. Atenção maior, porém, para as crianças, por intermédio de escolas bilíngues, excursões para montanhas, beira de grandes rios. Excursões previamente preparadas para visita a algumas cidades pré-selecionadas. E participações em pequenos parques infantis dotados de brinquedos tradicionais sabidamente admirados por todos os tipos de crianças, independentemente de etnias, cor ou vinculação sociocultural.

A face leste da Reserva Raposa/Serra do Sol é a mais problemática e exigente em termos de uma faixa periférica de proteção e atendimento aos grupos indígenas regionais. Pelo fato de estar em uma área de fronteira entre o Brasil e a República Comunitária das Guianas, a "reserva" ali demarcada carece da colaboração de diversos setores do Estado brasileiro. Ao que se acrescenta o fato de na fronteira do país vizinho existirem grupos indígenas de etnias, culturas e línguas iguais aos representantes da pré-história que sobrevivem no Brasil, nesse distante recanto da América tropical.

Em um plano para a faixa de fronteira, sob novo conceito de "buffer zone", sugerimos os seguintes miniprojetos, para serem implantados sempre a um ou dois, ou quatro a cinco quilômetros da margem direita do Rio Surumu: 
Familia de indio Macuxi caminba por área da Reserva Raposa/ Terra do Sol, em Roraima (RR).

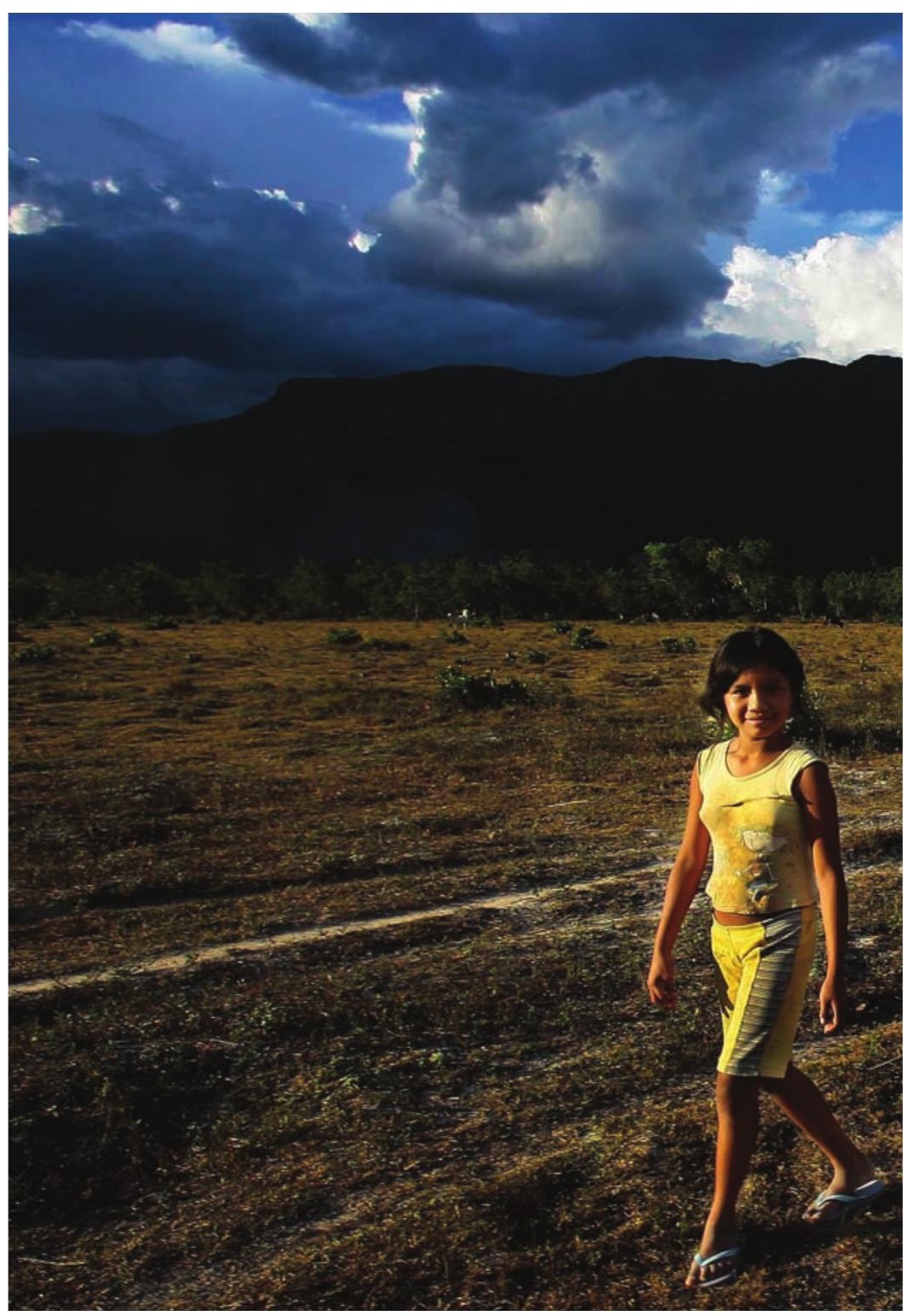

De Bom Fim para o norte - de cinco em cinco quilômetros - uma escola indígena bilíngue, envolvida por algumas pequenas construções, destinadas a alojamentos de professores e médicos em rodízio, saleta-auditório para reuniões culturais ou atividades das crianças indígenas.

Nessas minialdeias, separadas entre si por um espaço de aproximadamente cinco quilômetros, deverá existir sempre um posto de saúde, para atender crianças, jovens e adultos sujeitos a doenças de atendimento local relativamente fácil. Ficando pressuposto que casos mais graves exigirão transportes para hospitais em Boa Vista, Manaus ou alguns outros que venham a ser construídos e organizados na periferia oeste da reserva.

Em todos os núcleos-escola, deverá existir uma pequena biblioteca co- 
pré-selecionados, todos os dias, durante ou entre aulas [sugestões evidentemente a serem alteradas e enriquecidas].

O lado oeste da Reserva terá a responsabilidade de se organizar para atender as diferentes comunidades indígenas situadas no interior da Reserva e evitar $o$ ingresso de invasores como pessoas ou grupos vindos de qualquer região do Estado, da Amazônia ou alhures. Entre Boa Vista e BV8, na fronteira com a Venezuela, pensa-se em uma minialdeia parecida com a proposta feita para leste, porém contendo um núcleo administrativo da Funai, incluindo para tanto um pequeno heliporto.

O grande problema existente na face oeste da Reserva está relacionado com a facilidade de penetração de todos os tipos de especuladores provenientes das rasas colinas do lavrado ou dos sopés das serranias florestadas, ou da própria região de Boa Vista. Fato que implica a necessidade de um tipo bem planejado de "zona tampão", dentro da concepção aqui defendida, de faixas de transição, proteção, atendimento e discreta gestão administrativa.

Para prevenir impactos negativos, julgamos ser indispensável planejar unidades escolares de cinco em cinco quilômetros, no intervalo das quais algumas atividades agrícolas destinadas à alimentação dos grupos indígenas regionais. Ao lado das escolas mais frequentadas, um posto de saúde e um auditório para vídeos e computadores e o imprescindível miniparque de brinquedos para as crianças. A título de exemplo, um documentário importante para ser passado para crianças e adultos seria o caso de "O povo brasileiro", da fundação Darcy Ribeiro (DVD), e "Canudos: paixão e sangue nos sertões", entre outros.

Um cuidado especial deverá ser concedido às videotecas, as quais terão que possuir um acervo especial de documentários feitos com diferentes grupos indígenas, além de vídeos ou CD de valor cultural incontestáveis. Inicialmente dirigidos para crianças, com a presença eventual de adultos, uma vez ou mais por semana.

A face norte da Reserva Raposa/Serra do Sol apresenta razões especiais para uma proteção mais integrada e definitiva. A presença de florestas orográficas tropicais úmidas implica a necessidade de uma defesa radical do espaço total das regiões serranas regionais, incluindo morros florestados, seus solos frágeis, aguadas que descem para o lado brasileiro da fronteira da Grã-Sabana da Venezuela. Um patrimônio da natureza tropical brasileira fazendo contraste com o imenso altiplano savanoide dos Tepuy's do país vizinho.

Em um ponto piemôntico da morraria declivosa da região seria indicado implantar um alojamento para pesquisas e fiscalização. E, no alto do pico Roraima, em lugar discreto, que não afete a maravilhosa paisagem regional, existem razões para a instalação de um posto e alojamento singelo, semelhante àquele que foi implantado nos altos da região do Itatiaia, ofertado para uso discreto de pesquisadores, técnicos de governos e equipes de universidades brasileiras.

O maior problema dessa face norte da Reserva diz respeito aos piemontes das serranias, onde ocorrem solos tropicais, na faixa sinuosa de transição entre 
espaços do lavrado e os sopés das serras. Aí, sob as orientações de agrônomos e especialistas de solos, poderão ser instalados pequenos espaços agrícolas para produção de alimentos, frutas e hortaliças; enquanto as encostas florestadas, médias e altas, da Serra de Paracaima, devem ser totalmente preservadas, como espaços ecossistêmicos orográficos de exceção, até as altas bordas da Grã-Sabana da Venezuela. Uma proteção integrada dirigida para as florestas, os solos e as aguadas que abastecem a rede hidrográfica total do Estado de Roraima (bacia do Rio Branco). E, num futuro próximo, uma ou mais escolas bilíngues, de posição geográfica a estudar. A presença bem pensada do Estado constitui uma necessidade indispensável para atendimento efetivo aos diferentes grupos étnico-indígenas da reserva e, sobretudo, para evitar invasões de especuladores e apossadores contumazes de terras.

$\mathrm{Na}$ borda centro-sul da Reserva, onde já foram encontradas subáreas de solos agricultáveis, os problemas e conflitos entre invasores e grupos indígenas são mais complexos. Mesmo porque governantes e produtores rurais defendem uma demarcação descontínua da Reserva e alegam a importância econômica para o Estado de Roraima. Em contraposição a esse esforço de grilagem tardia, pseudolegalizável, pensamos que as principais manchas de culturas ali existentes devam ser consideradas enclaves de parcerias. E os lucros obtidos devem obrigatoriamente ser divididos, ficando uma parte para os fazendeiros invasores e outra, menor (da ordem de $30 \%$ ), para um fundo bem constituído, de atendimento múltiplo para a Reserva. Ficando bem explícito que nunca as áreas de cultivo inseridas na reserva por invasores possam vir a constituir terrenos da propriedade particular desses, ou seja, que em hipótese alguma possa existir algum tipo de grilagem forçada pelos produtores invasores, à custa de um incentivo antiético de governantes idiotizados.

É fato significativo e bem conhecido que o atual governador do Estado de Roraima defende a ideia de uma demarcação descontínua, nunca falando no fato de que com isso se pretende consolidar a posse cartorial de terras da Reserva indígena. Tem sido lançado o argumento de que os produtos dos "arrozeiros" são importantes economicamente para o Estado de Roraima, já que podem ser vendidos para o Amazonas e para a Venezuela.

A ideia de enclaves de parcerias sem direito à expansão progressiva e ao status de propriedade por si só resolve o mercado de commodities para a economia do Estado de Roraima. E com grandes vantagens para o atendimento e proteção de uma Reserva, estabelecida por lei para os herdeiros da pré-história, tão sofridos, humilhados e assassinados na história da colonização portuguesa na Amazônia, um dos maiores refúgios de homens provenientes do passado préhistórico conhecidos das Américas.

Quando alguém se dedicar a propor instalações especialmente sincopadas para "buffer zones" de uma reserva indígena, é lícito que se pergunte o que fazer com o corpo interno do espaço total dessas instalações. Eis uma tarefa quase exclusiva de antropólogos dotados de uma boa formação em aplicações de ciên- 
cias. Usando de toda a discrição e delicadeza imaginável, os que se dedicam à ciência do homem terão que, mais vagarosamente, estudar todas as aldeias dos diversos grupos indígenas internalizados na região, bem como os problemas nelas verificados no setor de saúde pública, alimentação, preservação cultural e intercomunicabilidade entre as etnias diversas ali existentes. A preservação de uma vivência comunitária, não encarceradora, deve ser de uma presença permanente nas diretrizes de gestão da Funai e do Supremo Tribunal Federal. E, em muitas situações, registrar quais os desejos e pretensões dos grupos indígenas em relação à perigosa ocidentalidade relativa existente no entorno da Reserva. Trata-se de uma tarefa lenta e difícil para os que se dedicam a uma verdadeira antropologia.

Para não falar da geografia humana dos povos de longuíssima data, que sobreviviam da caça, da coleta e da pesca, em um determinado território, como é o caso, até há pouco tempo, da Reserva da Raposa/Serra do Sol.

Alguém poderá comentar que seria muito difícil a solução de uma ajuda obrigatória dos arrozeiros invasores, como uma compensação pelo uso de terrenos da Reserva. Para tanto, o governo federal, por intermédio da Funai e do Incra, teria a obrigação de exigir os 30\% do lucro líquido da produção de arroz, pretensamente a ser vendido para a Venezuela, o Amazonas e a República Comunitária das Guianas. Os recursos obtidos deveriam participar de um fundo de atendimento para a Reserva, sob o controle de um conselho de líderes índios, educadores e representantes autônomos dos governos federal e estadual. Após cinco anos de atuação do Projeto, poderia ser feita uma avaliação sobre o comportamento dos invasores, em face dos interesses da Reserva, assim como sobre o equilíbrio e o andamento dos órgãos responsáveis pela discreta gestão da Reserva (em postos de saúde, hospitais, creches e escolas, estocagem de alimentos em armazéns da Reserva, núcleos de ensino agronômico, auditórios para reuniões, bibliotecas antropológicas e indigenistas, parques para as crianças, proteção do território indígena por guardas especiais, e edificações multiuso pela Funai). No mínimo, de nossa parte, dentro do conhecimento que dispomos em termos de aplicação de ciências para a sobrevivência dos legítimos herdeiros da pré-história - refugiados em distantes espaços do território brasileiro, sujeitos a duras e fratricidas pressões de um neocapitalismo regional -, prometemos dar continuidade progressiva a novas propostas, vindas de quem for e de onde vierem.

É uma grande pena cultural que governantes, políticos e fazendeiros nunca tenham sabido das observações criteriosas de Franz Boas, um dos grandes mestres das ciências do homem, que contribuiu para a formação cultural do brasileiro Gilberto Freyre.

Aziz Ab’Sáber é geógrafo, professor honorário do Instituto de Estudos Avançados da USP. @- absaber@usp.br

Recebido em 13.2.2008 e aceito em 20.2.2008. 